\title{
Effect of mineral fertilizer encapsulated with zeolite and polyethylene terephthalate on the soil microbiota, $\mathrm{pH}$ and plant germination
}

\author{
Iryna Rusyn*, Myroslav Malovanyy, Ivan Tymchuk, Serhiy Synelnikov \\ Department of Ecology and Sustainable Environmental Management, \\ Viacheslav Chornovil Institute of Sustainable Development, \\ Lviv Polytechnic National University, Lviv, Ukraine \\ "corresponding author e-mail: rib7@i.ua
}

Received: 30 June 2020 / Accepted: 17 September 2020

\begin{abstract}
Environmental risks caused by the use of traditional mineral fertilizers require new agro-technical solutions, which are encapsulated long-acting fertilizers. The use of the capsule allows to reduce the concentration of mineral compounds in the fertilizer and to minimize the adverse effects of the chemical compounds contained in it on the environment. Encapsulated fertilizers provide more efficient absorption of mineral nutrition by plants, allowing to synchronize the release of elements in accordance with the needs of the plant. The use of natural materials as fertilizer shells is faced with the problem of their low solubility and cost, and the use of synthetic coatings with the problems of their biodegradation in the environment. The development of new environmentally friendly materials for long-acting fertilizer capsules is a challenge for modern society. In this context, a universal mineral fertilizer coated with a coating of natural zeolite sorbent and diethylene glycol (DEG) modified polyethyl terephthalate (PET) is promising. We analyzed the influence of fertilizer on the kinetics of soil $\mathrm{pH}$ change, the dynamics of the total microbial count and the increase in the number of microorganisms and the germination of Hordeum sativum and Lolium perenne. The application of fertilizer for 28 days of the experiment led to decrease in soil $\mathrm{pH}$ by 0.3 . In the presence of encapsulated fertilizer the germination of ryegrass seeds was 3.51 times higher, and ones of barley 4.14 times higher than without fertilizer. The fertilizer provided a prolonged release of minerals, which had a positive effect on the germination of barley and ryegrass plants, stimulated plant growth and increased the total number of microorganisms in the soil as an important indicator of the efficiency of agricultural technology.
\end{abstract}

Keywords: long-acting fertilizers, soil, agro-technic, Hordeum sativum, Lolium perenne, total microbial count.

Abbreviations: diethylene glycol (DEG), polyethyl terephthalate (PET).

\section{Introduction}

Agricultural development of podzolic soils common in the north-western region of Europe is limited by a lack of nutrients and requires the application of mineral fertilizers. The use of traditional mineral fertilizers, which are applied to the soil once in high doses, involves longterm plant-fertilizer interaction directly in the soil, which leads to a number of risks. Plants do not fully use mineral fertilizer compounds, while nitrates, ammonium and phosphates accumulate in the environment, penetrate into groundwater and disturb the balance of soil microbiota (Prasad, 2013; Chen et al., 2018). At the same time, reduced yields and polluted environment are given at the cost of high energy consumption for the production of inefficient 
fertilizers (Pisarenko, 2008; Chen et al., 2018). Encapsulated fertilizers due to their prolonging ability to release nutrients provide more efficient assimilation by plants, prevent leaching of their components from the soil into groundwater and environmental pollution (Nazaryuk, 2007; Nahurskyi, 2011; Tymchuk \& Malovanyj, 2014). The use of the capsule allows to reduce the concentration of mineral compounds of the fertilizer and to minimize the adverse effects on the environment. For encapsulation of fertilizers use different types of coatings that have a decisive effect on the effectiveness of fertilizers: 1) mineral sulfur; 2) polymers of natural origin: chitosan, alginate, lignin, cellulose, etc. (Chen et al., 2018); 3) synthetic polymer elements: polyurethane rubber, polyethylene emulsion, ethylene vinyl acetate, polystyrenes, etc. (Lypyn et al., 2018).

Despite their positive characteristics, natural coatings have a number of disadvantages, such as the insolubility of chitosan (Sabadini et al., 2015), weak mechanical stability of alginate (He et al., 2015), low film-forming ability, insignificant solubility in water and easy destruction of starch in soil (Qiao et al., 2016), high cost of polydopamine (Feng et al., 2015), etc. Synthetic polymers are a promising type of fertilizer shell due to their low thickness, stability in the environment and the presence of tiny pores or semi-permeability of the material (Malavath et al., 2017). However, the composition of the shell can change the composition of the soil and have an adverse effect on the soil microbiota (Pan et al., 2016). Therefore, the development of new environmentally friendly fertilizers of prolonged action is an urgent problem. In this context, it is promising to use a combined shell based on the natural mineral zeolite in combination with a synthetic polymer. Zeolite is an aluminosilicate mineral, environmentally friendly sorbent that adsorbs water, aerates the soil, stimulates the development of the root system of plants (Rhodes, 2010). Microorganisms known for their biodegradable ability to decompose different type of resistant compounds of hydrocarbon origin (Rusyn et al., 2003; Glaser et al., 2019; Ghatge et al., 2020) expand the possibilities of using compounds with long-term decomposition in the environment. The use of PET in the shell of the fertilizer in the minimum amount has prospects due to the isolation from the media exposed to PET, the bacteria Ideonella sakaiensis 201-F6, which are able to use PET as the main source of energy and are capable to biodegradation of environmentally stable polymer in 1.5-2 vegetation period (Tanasupawat et al., 2016; Yoshida et al., 2016; Danso et al., 2018; Liu et al., 2018).

\section{Study area}

In this paper, we aim to investigate the agronomic efficiency of encapsulated universal mineral fertilizer of delayed action, coated with zeolite and modified polyethyl terephthalate, which allows the gradual release of minerals for agricultural crops of barley and ryegrass. Soil acidity is a mobile agrochemical feature that changes significantly with the introduction of chemicals and 
affects the digestibility of fertilizers (Trufanova, 2015). Functioning of microbial cenosis of soil is an indicator of its ecological condition, efficiency of agricultural machinery and its fertility (Samokhvalova et al., 2019). Barley is an important crop, for which in 2017 in Ukraine was allocated 2469 thousand hectares and is projected to increase the sowing area to 2.5-2.6 million hectares (Kliuchnikova, 2018). Ryegrass is a good model object as a fast-growing plant (Hannaway et al., 1999). Therefore, the task was to analyze the dynamics of soil pH, total microbial count, growth of microorganisms and germination of barley and ryegrass with the addition of modified polyethyl terephthalate-zeolite-encapsulated mineral fertilizer.

\section{Matherial and methods}

\subsection{Fertilizer}

In the experiments we used granular highly concentrated nitro-phosphate-potassium with sulfate fertilizer in the proportion N16: P16: K16: S7, covered with a double shell of modified polyethyl terephthalate (PET) and zeolite. This is a universal mineral fertilizer, the nutrients of which are contained in the form of water-soluble and readily available to plants compounds.

To obtain a polymer shell, PET waste in the form of flakes was modified with diethylene glycol (DEG) at $493 \mathrm{~K}$ and $20 \mathrm{kPa}$ as described in (Gak, 2011). The formed modified polymer had the structure shown in Figure 1.

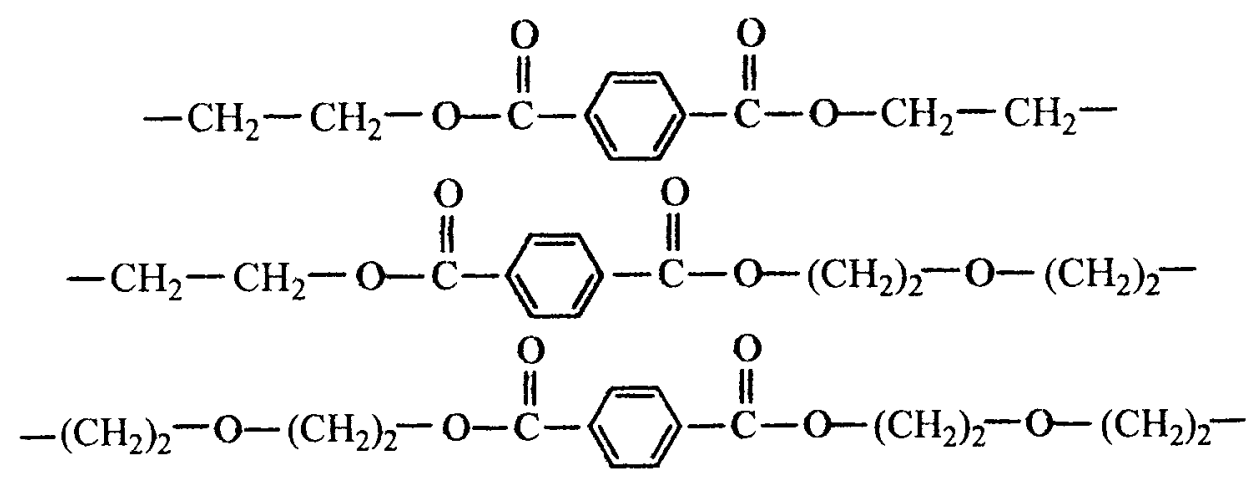

Figure 1. Structure of fragments of DEG modified PET macromolecules, which together with zeolite covered mineral fertilizer

During the polymer encapsulation and after its completion, zeolite dusting was performed as described in (Nahurskyi, 2011). The capsule occupied 10\% of the mass of fertilizer.

\subsection{Conducting of experiment}

In the experiments, a dark gray podzolic gley loamy soil with a humus content of 2.9 was used. The soil for analysis was prepared using sieves w 5.6, d 1.6 and w 2.0 d $0.9200 \mathrm{~g} / 1$ sample. 
$140 \mathrm{~g}$ of prepared dry soil was placed in plastic cups volume of $200 \mathrm{ml}$ with a drainage, the soil was moistened and 3 granules of fertilizer were placed on its surface, which was covered with a $1 \mathrm{~cm}$ layer of soil and 5 seeds of Lolium perenne L. (Perennial ryegrass) or Hordeum sativum Jessen (barley), then were covered with a $1 \mathrm{~cm}$ layer of soil and watered (Fig. 2). Samples without fertilizers with the soil and with plants were used as controls. For plant germination, the cups were covered with film, creating mini-greenhouses. The samples were moistened as the soil dried every two days. The experiment was performed with three replicates in the laboratory at $18^{\circ} \mathrm{C} \pm 2^{\circ} \mathrm{C}$ using natural light.
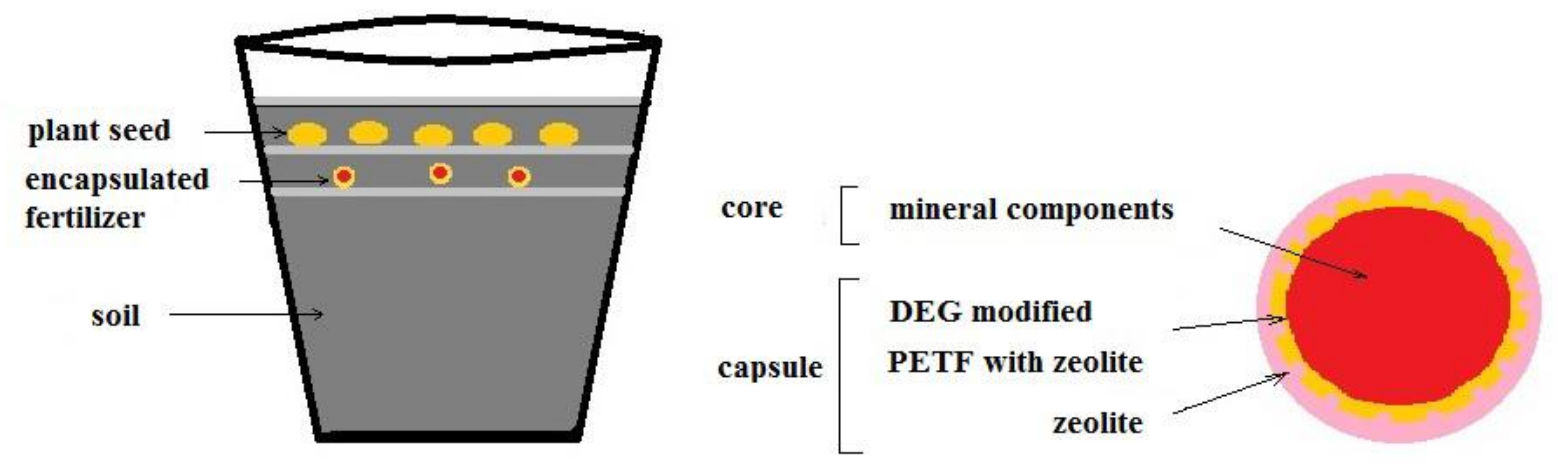

a

$\mathrm{b}$

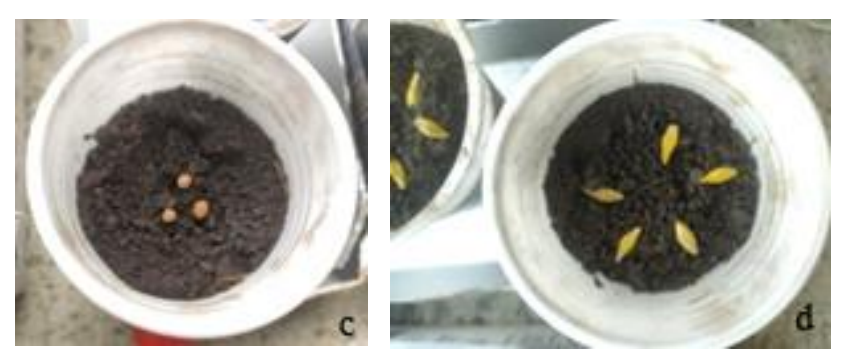

Figure 2. The scheme of the experiment. Notation: the scheme of the sample with soil, fertilizer and seeds (a), schematic structure of fertilizer (b), three granules of encapsulated fertilizer were placed on the soil surface (c), five plant seeds were placed on a one-centimeter layer of soil covering the fertilizer, and then covered with a one-centimeter layer of soil (d)

\subsection{Microbiological analysis and determination of $\mathbf{p H}$}

The average soil sample was taken according to GOST 17.4.4.02-84 (2006). The $\mathrm{pH}$ of the liquid phase of the soil was determined using a digital pH meter HI98103 with a glass electrode. A soil sample weighing $20 \mathrm{~g}$ and $20 \mathrm{ml}$ of distilled water was added to a glass flask and stirred for 5 minutes, the resulting soil mixture was allowed to stand for 1 hour. Using a filter, the liquid phase was separated and its $\mathrm{pH}$ was measured using a $\mathrm{pH}$ meter, immersing the electrode to a depth of $4 \mathrm{~cm}$.

For the preparation of microscopic preparations by the Vinogradsky-Breed's method, 10 $\mathrm{g}$ of soil was weighed from the average soil sample, ground in a mortar and mixed with $90 \mathrm{ml}$ of 
sterile distilled water for 10 minutes. The soil suspension was defended for the sedimentation of coarse particles and made a series of dilutions. The micropreparations were made from $0.01 \mathrm{ml}$ of soil suspensions, dried, fixed with $96 \%$ ethyl alcohol and stained with carbolic erythrosine for 30 minutes. The number of bacteria in the soil was determined by direct counting under a microscope using an immersion system in 100 fields of view of the eyepiece of the microscope (Lebid \& Fedorovych, 2013).

The total number of microorganisms was determined by the formula:

$$
x=q \cdot \frac{S_{m} \cdot 10^{8} \cdot C}{S_{n .3} \cdot V}
$$

where $\mathrm{q}$ - the average number of microorganisms in the field of view; $\mathrm{S}_{\mathrm{m}}$ - smear area, $\mathrm{cm}^{2} ; 10^{8}$ conversion to micrometers, $\mu \mathrm{m}^{2} ; \mathrm{C}$ - dilution; $\mathrm{S}_{\text {п.з. }}$ - field of view area, $\mu \mathrm{m}^{2} ; \mathrm{V}$ - volume of test suspension.

To calculate the number of bacteria in $1 \mathrm{~g}$ of absolutely dry soil, the number found was multiplied by the degree of dilution and divided by the mass of absolutely dry soil contained in 1 $\mathrm{g}$ of raw soil. The content of absolutely dry soil was determined in $1 \mathrm{~g}$ of the analyzed moist soil by drying the boxes at at $105^{\circ} \mathrm{C}$ to constant weight. The increase in the total number of microorganisms in $1 \mathrm{~g}$ of soil was calculated as the difference between their calculated values at the beginning and the end of the first, second, third and fourth weeks of the experiment. The results were processed statistically. The reported results were presented as the average of all replicate experiments and their standard errors $(x \pm S E)$. Significance of difference between average values was established using one-way analysis of variance and F-test for 95\% confidence level.

Microbial associations directly in their natural soil environment were studied by the method of fouling plates according to M. G. Kholodny (Lebid \& Fedorovych, 2013). To do this, an incision was made on a flat surface of the soil, a sterile degreased slide was tightly applied to the vertical wall of the section. The slides were placed at different depths to study the microorganisms of the soil with fertilizers and plant seedlings. Deeply located glasses were covered with soil and their locations were marked. The slides were kept in the soil throughout the experiment. After that, the ground was carefully removed and the glass was removed. The surface of the glass, which was pressed against the wall of the soil section, was dried in air. The opposite side of the glass was wiped with a dry cloth. The preparation was fixed on the flame of the burner. After that, the slide was immersed in a jar of water upside down, as a result of which large soil particles get wet and fall to the bottom, and microorganisms remain on the glass. After washing, the preparation was stained with carbolic erythrosine, the dye was incubated from 30 min to $24 \mathrm{~h}$, dried and examined under a microscope with an immersion system. 


\section{Results and Discussion}

On the first day of the experiment and the next day of the experiment, the number of microorganisms in $1 \mathrm{~g}$ of soil differed slightly (Fig. 3). On the 7th day of the experiment, the total microbial count in soil increased in all samples and, especially, in samples with fertilizer. The increase in the quantity of microorganisms in the samples with fertilizer was by $8.7-9.1 \%$ $(1,075,718-1,132,820)$, while in the samples of soil without fertilizer the difference between the 1 st and 7th day of the experiment was only 2.3 - 3.5\% (282,702 - 440,398) (Fig. 4). Apparently, nitrates and ammonium, which were gradually released when the fertilizer was dissolved, contributed to the numerical development of nitrifying and denitrifying bacteria compared to samples without fertilizer. The increase in the number of microorganisms in samples without fertilizer is associated with the activation of soil microcenose due to its moisture and development due to the substrates contained in the soil.

During the 14th - 28th day of the experiment, an even more active further increase of the total microbial count in samples with fertilizer and plants was recorded in comparison with control samples without fertilizer (Fig. 3). Thus, on the 14th day of the experiment, the rise in the quantity of microorganisms in samples with soil and fertilizer was recorded by $3.7 \%(518,918)$, in samples with fertilizer and plants by $4.9 \%(692,830)$ and $5.9 \%(843,323)$, and in samples without fertilizers only $1.8-2.8 \%(227,021-369,703)$ (Fig. 4). Similar trends were observed on the 21st day of the experiment: the increase in the number of microorganisms was most significant in the samples with fertilizer and ryegrass or barley and was 4.8 and $5.6 \%(713,385$ and 843,368), respectively; in the samples with plants and without fertilizer there was also an increase, but less intensive, by $2.5 \%(341,490)$ with ryegrass and by $2.9 \%(390,729)$ with barley; in the samples with soil-fertilizer the growth was $2.5 \%(369,793)$. At the same time, in soil samples without fertilizer, the growth of the total microbial count slowed down further and was already only $1.2 \%(161,865)$ on the 21 st day of the experiment. On the 28 th day of the experiment, the total microbial count in $1 \mathrm{~g}$ of soil again actively increased in the samples with fertilizer and barley or ryegrass by $6.7 \%$ and $6.0 \%$, respectively; in samples with plants, but without fertilizer, the rise was less intense and amounted to $3.6 \%$. The increase in the quantity of microorganisms with fertilizer and soil without plants was even less active and the increase in the total microbial count was only $0.7 \%$ on the 28 th day of the experiment. The number of microorganisms in the soil without fertilizer and without plants decreased, apparently due to the depletion of the substrates contained in the soil and the increase was negative. As can be seen from Figure 4, which illustrates the dependence of the growth of the total count of microorganisms on the duration of the experiment, the growth of microorganisms in soil samples without fertilizer, as in the soil-fertilizer sample slowed down compared to other samples with plants and plants and fertilizer. Throughout the experiment, the fertilizer stimulated the growth 
of quantity of microorganisms. Obviously, the intensive germination of plants under the influence of prolonged release of mineral fertilizers caused active photosynthesis and excretion of organic matter into the soil, which are substrates for the development of a large number of microorganisms. The probable cause of less active growth of microbial count in samples with plants, but without fertilizers was less intensive germination and development of plants, in conditions of nutrient limitation and, accordingly, less intense secretion of organic compounds of photosynthesis into the soil. Fertilizers can also directly stimulate the growth of microbial populations (Nakhro \& Dkhar, 2010). The microbial community is sensitive to the availability of nitrogen and the pH changes when the fertilizer dissolves (Frey et al., 2004; Lauber et al., 2009). The soil microbiota of all samples was diverse and represented by spherical, ro-shaped and branched forms.

The $\mathrm{pH}$ of the soil of all samples on the 1st day and the 2 nd day of the experiment differed slightly and was 6.97-7.05 (Table 1). On the 7th day of the experiment the $\mathrm{pH}$ of the samples with the fertilizer decreased slightly and on the 14-28th day of the experiment the $\mathrm{pH}$ of the samples with the fertilizer was slightly lower than the samples without the fertilizer (Table 1). Lowering the $\mathrm{pH}$ of soil samples with fertilizer compared to control samples was a sign of gradual release of fertilizer components and is a positive factor, as weakly acidic soil $\mathrm{pH}$ is optimal for most crops, that increases the availability of nutrients for plant. $\mathrm{pH}$ of soil samples was statistically insignificantly reduced during the experiment after adding fertilizer to 0.3 on the 28th day of the experiment $(\mathrm{p}>0.647)$. Similar results were obtained in the work Trufanova (2015), where the introduction of nitroammophos in comparison with the control, slightly reduces the $\mathrm{pH}$ by $0.1-0.2$ and 0.3 with additional introduction of potassium sulfate.

Table 1. $\mathrm{pH}$ kinetics of the aqueous phase of soil samples within 28 days after fertilizer addition $(\mathrm{x} \pm \mathrm{SE}, \mathrm{n}=3)$

\begin{tabular}{|c|c|c|c|c|c|c|c|}
\hline \multicolumn{2}{|c|}{ Day } & & & & & \\
Sample & & & & & \\
Fertili & Plant & & & & & & \\
zer & & & & & & & \\
\\
\hline+ & - & $7.02 \pm 0.03$ & $6.98 \pm 0.05$ & $6.88 \pm 0.07$ & $6.68 \pm 0.06$ & $6.61 \pm 0.06$ & $6.74 \pm 0.08$ \\
\hline+ & ryegrass & $6.97 \pm 0.02$ & $6.99 \pm 0.04$ & $6.85 \pm 0.05$ & $6.70 \pm 0.07$ & $6.64 \pm 0.05$ & $6.71 \pm 0.09$ \\
\hline+ & barley & $7.01 \pm 0.04$ & $7.00 \pm 0.06$ & $6.87 \pm 0.06$ & $6.72 \pm 0.09$ & $6.65 \pm 0.06$ & $6.70 \pm 0.05$ \\
\hline- & - & $7.05 \pm 0.03$ & $6.99 \pm 0.07$ & $7.06 \pm 0.05$ & $7.08 \pm 0.08$ & $6.98 \pm 0.07$ & $7.08 \pm 0.08$ \\
\hline
\end{tabular}




\begin{tabular}{|c|c|c|c|c|c|c|c|}
\hline- & ryegrass & $6.99 \pm 0.05$ & $7.02 \pm 0.05$ & $7.09 \pm 0.09$ & $7.02 \pm 0.05$ & $7.02 \pm 0.08$ & $6.95 \pm 0.09$ \\
\hline- & barley & $6.98 \pm 0.04$ & $6.98 \pm 0.05$ & $7.00 \pm 0.08$ & $7.04 \pm 0.06$ & $7.00 \pm 0.06$ & $7.01 \pm 0.07$ \\
\hline
\end{tabular}

The fertilizer had a positive effect on the germination of seeds of all analyzed plants. Without fertilizer, the seeds germinated slowly and in small quantities, while with the addition of fertilizer germination was several times higher (Fig. 5). On the 7th day from sowing, the first sprouts of plants emerged. 10 days after the start of the experiment, germination of ryegrass and barley was observed in most samples with fertilizer, while without fertilizer the seeds have not yet germinated. On the 14th day of the experiment, $36.0 \%$ of barley seeds germinated with fertilizer, while only $3.2 \%$ of barley germinated without fertilizer. With fertilizer $72.8 \%$ of ryegrass seeds were sprouted up, and only $17.6 \%$ without fertilizer on the 14th day of the experiment. On the 21st and 28th day of the experiment, the germination of barley was $40.0 \%$ with fertilizer and only $5.6 \%$ without fertilizer. The fertilizer had an even more intense effect on ryegrass germination: $98.4 \%$ of seeds germinated on the 21 st and 28 th day of the experiment and only $28.0 \%$ without fertilizer (Figs. 5, 6). The release of nutrients is gradual and promotes plant germination. In encapsulated fertilizers, mineral soluble compounds are covered with a protective film, which controls the penetration of water into the granules, the level of dissolution of the fertilizer components and allows to synchronize the release of elements to the needs of the plant (Lypyn et al., 2018). In the process of plant growth, fertilizer granules adsorb water that dissolves mineral salts. As a result of osmotic pressure, the dissolved elements pass through the capsule to the outside, where they are gradually absorbed by the roots of the plant throughout the entire growing season of crops (Malavath et al., 2017) and facilitate plant growth.

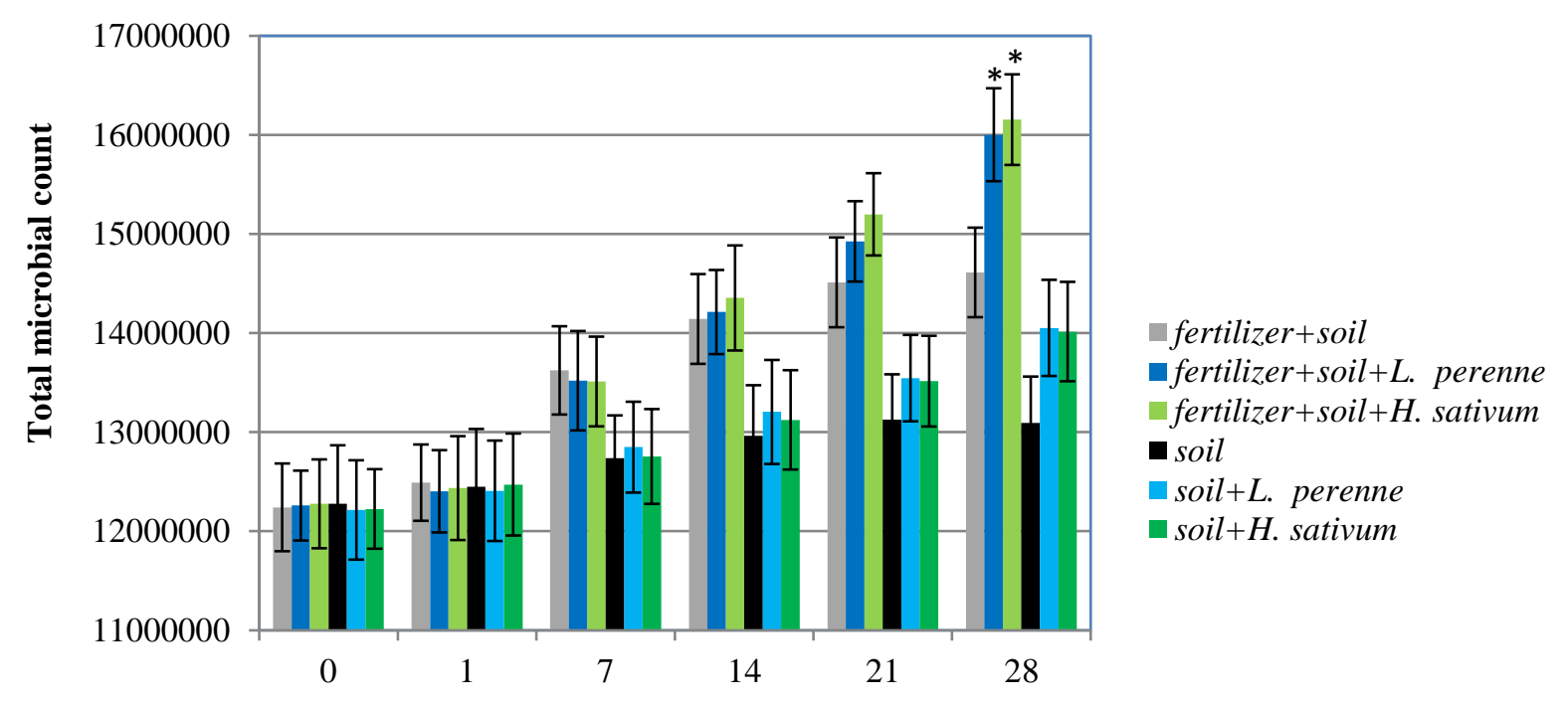

Duration of plant cultivation, days

Figure 3. Total microbial count in soil without plants and soil of root zone of barley and ryegrass in $1 \mathrm{~g}$ of absolutely dry soil with and without fertilizer addition within 28 days after 
application of agro-technic $(\mathrm{x} \pm \mathrm{SE}, \mathrm{n}=3)$. $*$ The difference between the total microbial count in the samples with soil without fertilizer and the samples with fertilizer and ryegrass or barley was statistically significant $(\mathrm{P}<0.05)$

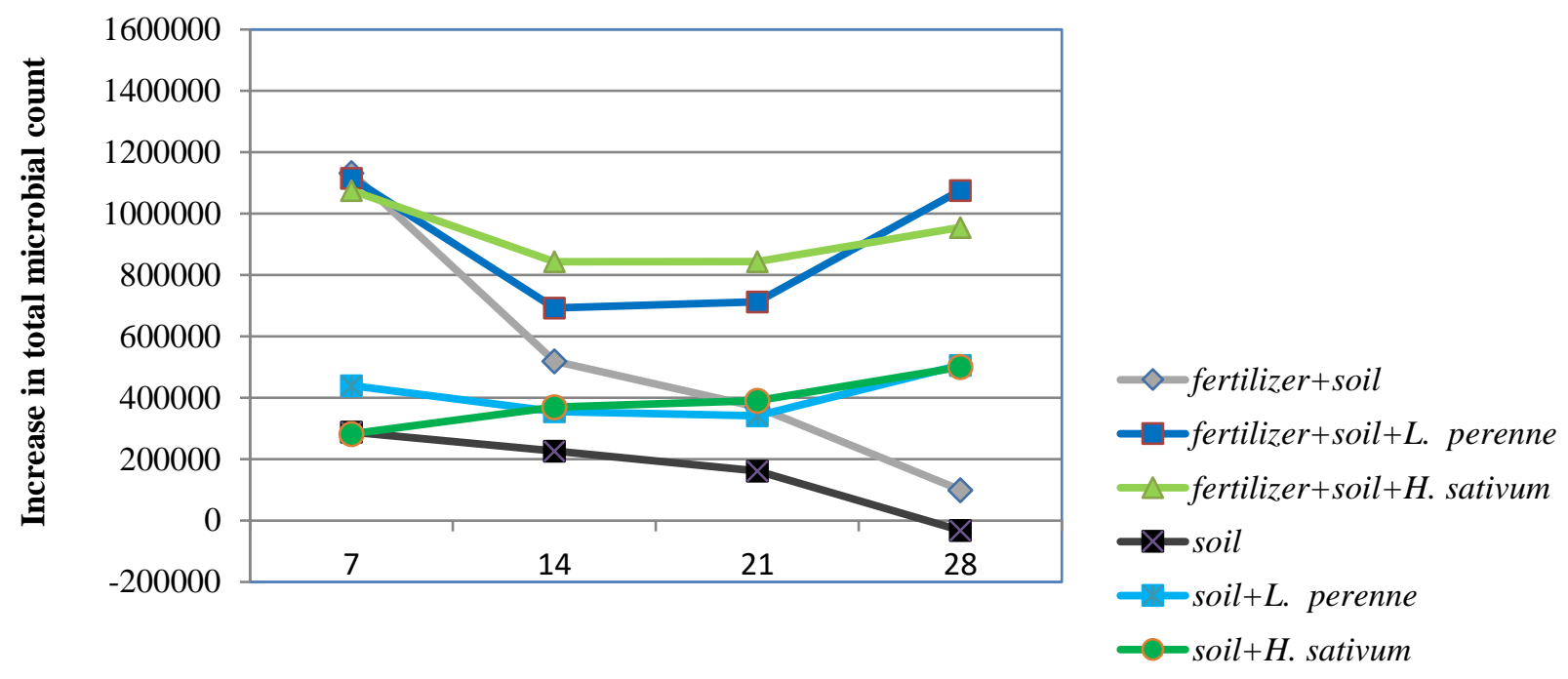

Duration of experiment, days

Figure 4. Increase in the total microbial count in $1 \mathrm{~g}$ of soil for 28 days

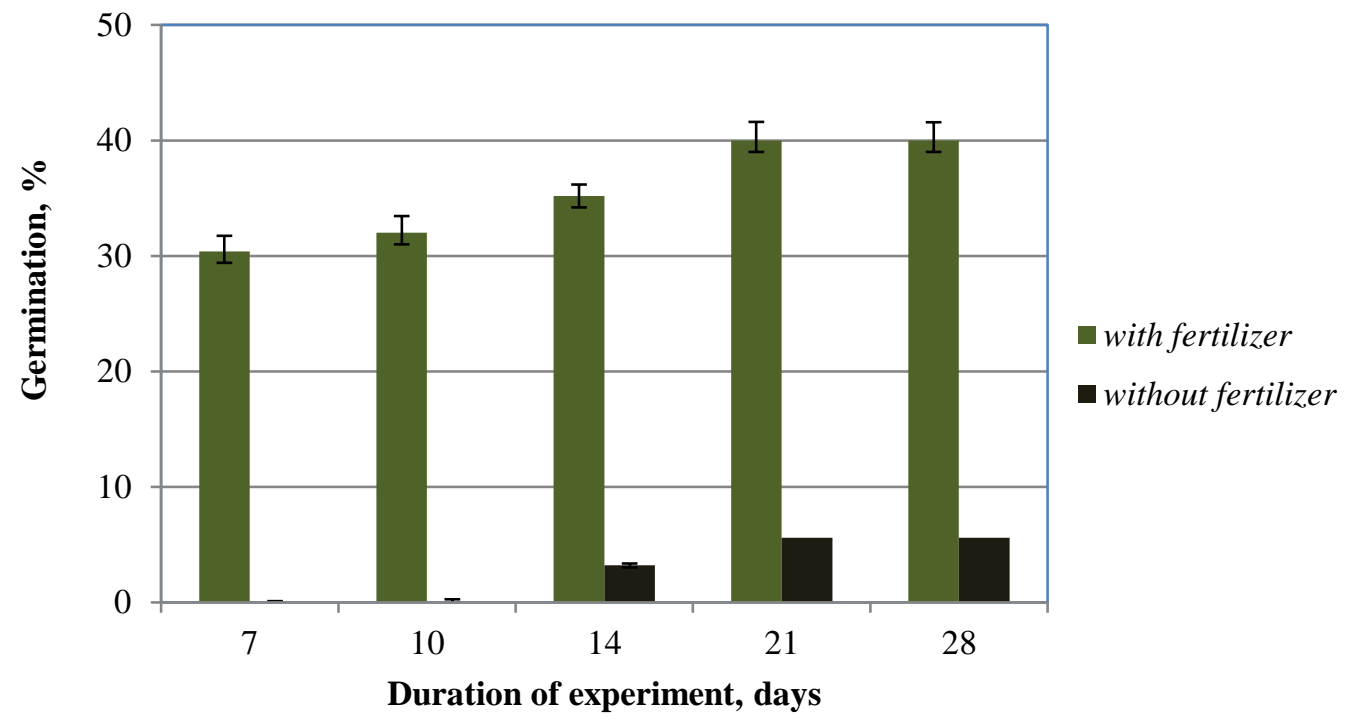




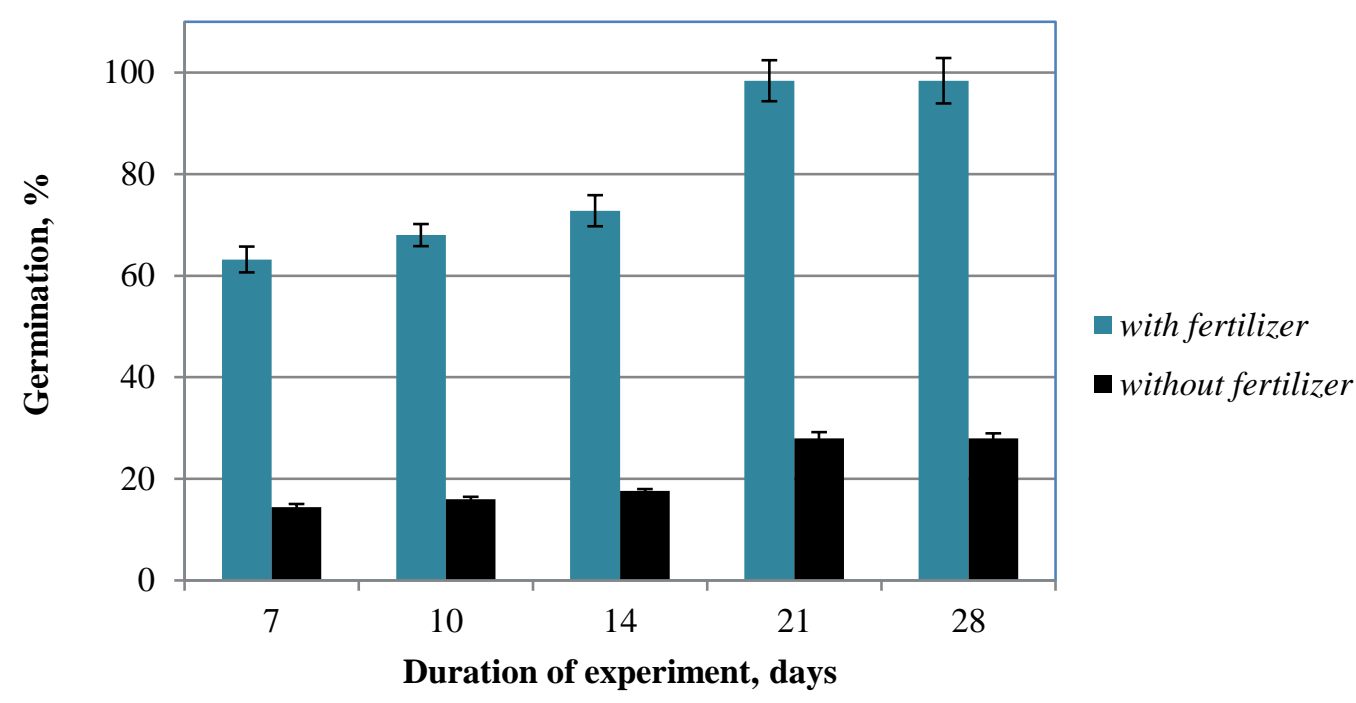

Figure 5. Influence of fertilizer on germination of barley plants (a) and ryegrass (b) $(x \pm S E, n=3)$

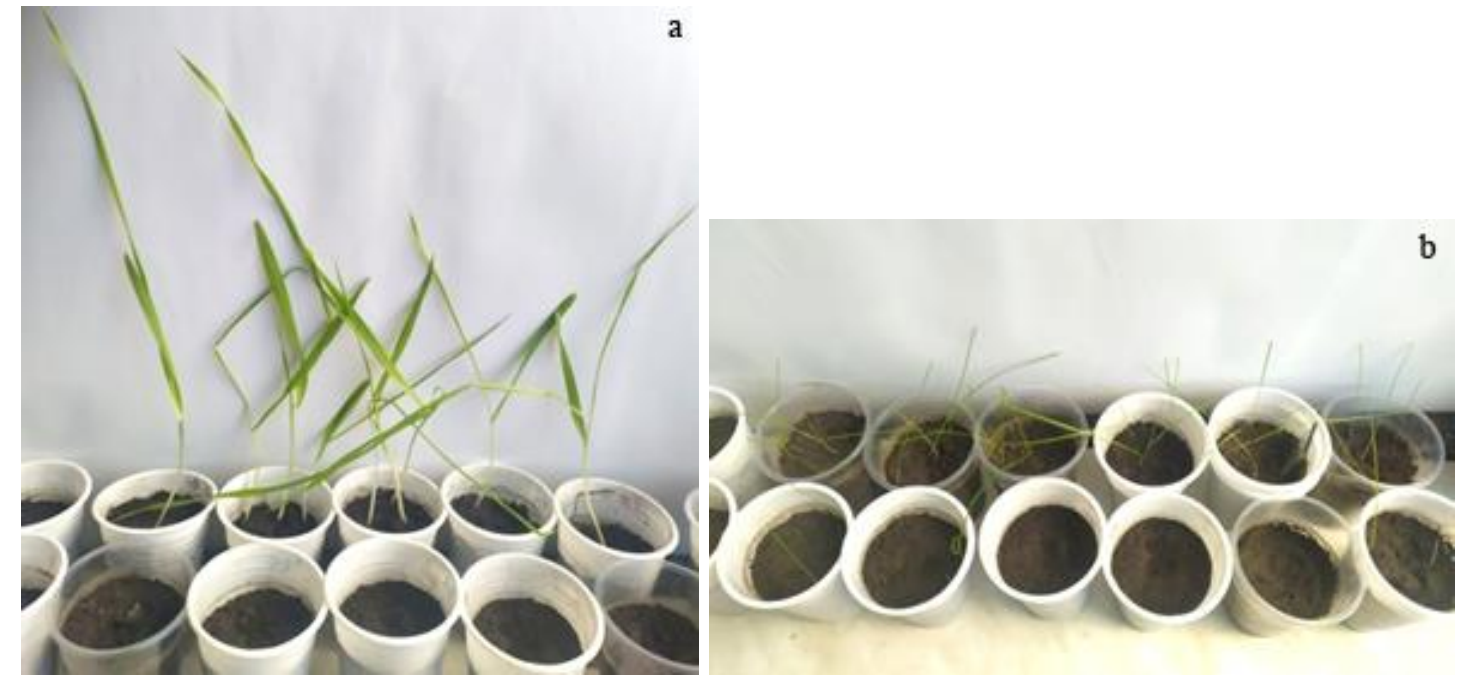

Figure 6. Effect of fertilizer on germination of barley plants (a) and ryegrass (b) during 28 days of the experiment. Without fertilizer (cups in the first near row) plant germination is much lower than in samples with fertilizer (cups in the 2nd row)

\section{Conclusion}

Granular universal mineral fertilizer encapsulated with modified polyethyl terephthalate and zeolite with prolonged release of minerals had positive effect on the germination of plants of barley and ryegrass. The composition of the shell did not show adverse effects on the soil microbiota, vice versa increased the total count of microorganisms in the soil and slightly reduced soil $\mathrm{pH}$. The application of encapsulated fertilizers in agro-technic can increase the efficiency of agricultural development of soils with a limited amount of nutrients. 


\section{References}

Chen J., Lü S., Zhang Z., Zhao X., Li X., Ning P. \& Liu M., 2018, Environmentally friendly fertilizers: A review of materials used and their effects on the environment. Science of the Total Environment 613/614: 829-839.

Danso D., Schmeisser C., Chow J., Zimmermann W., Wei R., Leggewie C. \& Streit W.R., 2018, New Insights into the Function and Global Distribution of Polyethylene Terephthalate (PET)-Degrading Bacteria and Enzymes in Marine and Terrestrial Metagenomes. Applied and Environmental Microbiology 84 (8): 13.

Feng C., Lü S., Gao C., Wang X., Xu X., Bai X., Gao N., Liu M. \& Wu L., 2015, "Smart" fertilizer with temperature-and $\mathrm{pH}$-responsive behavior via surface-initiated polymerization for controlled release of nutrients. ACS Sustainable Chemistry \& Engineering 3: 3157-3166.

Frey S.D., Knorr M., Parrent J.L. \& Simpson R.T., 2004, Chronic nitrogen enrichment affects the structure and function of the soil microbial community in temperate hardwood and pine forests. Forest Ecology and Management 196: 159-171.

Gak V.S., 2011, Rozrobka ta vlastyvosti plivkoutvoriuvachiv dlia fleksohrafskykh farb na osnovi vtorynnoho polietylentereftalatu [Development and properties of film formers for flexographic paints based on secondary polyethylene terephthalate]. Dysertatsiias Tekhnolohiia polimernykh i kompozytsiinykh materialiv. NU „Lvivska politekhnika”, Lviv (in Ukrainian).

Ghatge S., Yang Y., Ahn, J. \& Hur H., 2020, Biodegradation of polyethylene: a brief review. Applied Biological Chemistry 63: 1-14.

Glaser J.A. Biological Degradation of Polymers in the Environment, 2019, In: Gomiero A. (Ed) Plastics in the Environment. Norwegian Research Center AS, Intech open.

GOST 17.4.4.02-84, 2006, Mejgosudarstvennyiy Standart. Ohrana prirody. Pochvy. Metody otbora i podgotovki prob dlya himicheskogo, bakteriologicheskogo, gelmintologicheskogo analiza. [Interstate standard. Nature protection. Soils. Methods of selection and preparation of soils samples for chemical, bacteriological, helmintological analysis]. Izdatelstvo standartov, Standartinform, Moskva (in Russian).

Hannaway D., Fransen S., Cropper J., Teel M., Chaney M., Griggs T., Halse R., Hart J., Cheeke P., Hansen D., Klinger R. \& Lane W., 1999, Perennial ryegrass (Lolium perenne L.), PNW 503: 1-20.

He Y., Wu Z., Tu L., Han Y., Zhang G. \& Li C., 2015, Encapsulation and characterization of slow-release microbial fertilizer from the composites of bentonite and alginate. Applied Clay Science 109: 68-75.

Kliuchnikova N., 2018, Yak zminylysia posivy na ukrainskykh poliakh za 10 rokiv? [How have the crops in the Ukrainian fields changed over 10 years?]. https://agroportal.ua/ua/publishing/infografika/kak-izmenilis-posevy-na-ukrainskikhpolyakh-za-10-let

Lauber C.L., Hamady M., Knight R. \& Fierer N., 2009, Pyrosequencing-based assessment of soil $\mathrm{pH}$ as a predictor of soil bacterial community structure at the continental scale. Applied and Environmental Microbiology 75: 5111-5120.

Lebid S.H. \& Fedorovich H.T., 2013, Osnovy zahalnoi mikrobiolohii [Fundamentals of general microbiology]. Vydavnytstvo ChDU im. Petra Mohyly, Mykolaiv.

Liu B., He L., Wang L., Li T., Li C., Liu H., Luo Y. \& Bao R., 2018, Protein Crystallography and Site-Direct Mutagenesis Analysis of the Poly(ethylene terephthalate) Hydrolase PETase from Ideonella sakaiensis. ChemBioChem 19 (14): 1471-1475.

Lypyn A.H., Nebukyn V.O. \& Lypyn A.A., 2018, Kapsulyrovanye hranul v polymernye obolochky kak metod sozdanyia myneralnykh udobrenyi s rehulyruemoi skorostiu vysvobozhdenyia pytatelnykh veshchestv [Encapsulation of granules in polymer shells as a method of creating mineral fertilizers with adjustable rate of nutrient release], 
Sovremennye-naukoemkye tekhnolohyy. Rehyonalnoe prylozhenye 3(51): 86-91 (in Russian).

Malavath B., Kumar R. \& Manasa K., 2017, Polymer coated fertilizers as advance technique in nutrient management. An Asian Journal of Soil Science 12(1): 228-232.

Nahurskyi O.A., 2011, Kapsuliuvannia hranulovanykh mineralnykh dobryv plivkamy na osnovi polimernykh vidkhodiv $\mathrm{v}$ aparati psevdozridzhenoho stanu [Encapsulation of granular mineral fertilizers with films based on polymer waste in a fluidized bed apparatus]. Visnyk Natsionalnoho Tekhnichnoho Universytetu „Kharkivskyi politekhnichnyi instytut". Novi rishennia u suchasnykh tekhnolohiiakh 23: 21-25 (in Ukrainian).

Nakhro N. \& Dkhar M.S., 2010, Impact of Organic and Inorganic Fertilizers on Microbial Populations and Biom ass Carbon in Paddy Field Soil. Journal of Agronomy 9(3): 102 110.

Nazaryuk V.M., 2007, Pochvenno-ekologicheskie osnovy optimizacii pitaniya rastenij [Soil and ecological bases of plant nutrition optimization]. Izd-vo SO RAN, Novosibirsk (in Russian).

Pan P., Jiang H., Zhang J., Yang J., Li S., Liu S., Zhang S. \& Lei M., 2016, Shifts in soil bacterial communities induced by the controlled-release fertilizer coatings. Journal of Integrative Agriculture 15(12): 2855-2864.

Prasad R., 2013, Population growth, food shortages and ways to alleviate hunger. Current Science 105: 32-36.

Pisarenko V.N., 2008, Ekologicheskie problemy pri ispolzovanii mineralnyh udobrenij: Puti vozmozhnogo zagryazneniya okruzhayushej sredy udobreniyami i meropriyatiya po ego predotvrasheniyu [Environmental problems when using mineral fertilizers: Ways of possible environmental pollution by fertilizers and measures to prevent it]. Agroekologiya, Poltava (in Russian).

Qiao D., Liu H., Yu L., Bao X., Simon G. P., Petinakis E. \& Chen L., 2016, Preparation and characterization of slow-release fertilizer encapsulated by starch-based superabsorbent polymer. Carbohydrate Polymers 147: 146-154.

Rhodes C.J., 2010, Properties and applications of zeolites, Science Progress 93(3): 223-284.

Rusyn I.B., Moroz O.M., Karabyn V.V., Kulachkovs'kii O.R. \& Hudz' S.P., 2003, Biodehradatsiia vuhlevodniv nafty drizhdzhamy rodu Candida [Biodegradation of oil hydrocarbons by Candida yeast]. Mikrobiolohichnyi Zhurnal (Kiev, Ukraine: 1993) 65 (6): 36-42 (in Ukrainian).

Sabadini R.C., Martins V.C.A. \& Pawlicka A., 2015, Synthesis and characterization of gellan gum: chitosan biohydrogels for soil humidity control and fertilizer release. Cellulose 22: 2045-2054.

Samokhvalova V., Starchenko O., Chebanova V., Chaban V., Podobed O. \& Samokhvalova P., 2019, Vyznachennia mikroelementnoho skladu hruntu za yoho mikrobiolohichnymy ta biokhimichnymy pokaznykamy transformatsii spoluk tsyklu nitrohenu [Determination of microelement composition of soil by its microbiological and biochemical indicators of transformation of nitric cycle compounds]. Visnyk Lvivskoho universytetu. Seriia biolohichna 80: 129-145 (in Ukrainian).

Tanasupawat S., Takehana T., Yoshida S., Hiraga K. \& Oda K., 2016, Ideonella sakaiensis sp. nov., isolated from a microbial consortium that degrades poly(ethylene terephthalate). International Journal of Systematic and Evolutionary Microbiology 66: 2813-2818.

Trufanova A. A., 2015, Vliyanie kompleksnyh udobrenij na svojstva pochv [The effect of complex fertilizers on soil properties]. Biologicheskie nauki, 548-553 (in Russian).

Tymchuk I. \& Malovanyj M., 2014, Kapsulirovanie udobrenij - put k snizheniyu zagryazneniya i povysheniya urozhajnosti [Fertilizer encapsulation - a way to reduce pollution and increase productivity]. Ustojchivoe razvitie, Varna, 23: 151-156 (in Russian).

Yoshida S., Hiraga K., Takehana T., Taniguchi I., Yamaji H., Maeda Y., Toyohara K., Miyamoto K., Kimura Y. \& Oda K., 2016, A bacterium that degrades and assimilates poly(ethylene terephthalate). Science 351 (6278): 1196-1199. 